\title{
HUKUM DAN RADIKALISME AGAMA DI INDONESIA
}

\author{
Oleh: M. Jamil ${ }^{1}$
}

Tahun 2015 silam, salahsatu anggota Dewan Pewakilan Daerah Republik Indonesia, Farouk Muhammad dalam bukunya pernah menerawang akan kondisi bangsa terkait radikalisme, beliau mengatakan bahwasannya memasuki usianya yang ke-70, bangsa dan negara Indonesia tampaknya akan terus diuji untuk menyelesaikan sejumlah persoalan dalam menjaga karakternya sebagai bangsa yang plural dan majemuk. Salah satu agenda mendesak yang sudah semestinya menjadi perhatian kita bersama adalah isu tentang penanganan konflik-konflik sosial bernuansa agama (Farouk Muhammad, 2015: 17). Hasil terawangan tersebut, kini benar-benar terbukti adanya. Dewasa ini banyak kita temukan penyimpangan yang keluar dari aturan secara legal formal berlaku di Indonesia, salahsatunya terkait radikalisme.

Negara Indonesia adalah negara hukum, begitu bunyi Pasal 1 Ayat (3) amandemen ketiga Undang-Undang Dasar Negara Republik Indonesia Tahun 1945 (UUD 1945). Karena Negara Kesatuan Republik Indonesia (NKRI) menganut Negara hukum, maka dalam suatu negara hukum semua orang harus diperlakukan sama dihadapan hukum (equality before the law). Oleh karenanya, setiap orang yang melakukan perbuatan melawan hukum, termasuk pelaku radikalisme, maka akan menerima konsekwensi hukum atas apa yang ia perbuat (M. Jamil[1], 2016: 23). R. Soepomo memandang bahwa setiap hukum merupakan suatu sistem, yang mana peraturan-peraturannya merupakan suatu kebulatan berdasarkan alam pikiran (M. Jamil[2], 2016: 43). Oleh karenanya membangun Indonesia agar lebih besar dan lebih bermartabat lagi, kita harus

\footnotetext{
${ }^{1}$ Ketua Umum Pusat Studi Mahasiswa Pascasarjana (PUSMAJA) Mbojo-Yogyakarta Periode 2015-2017 | | Ketua II Bagian Eksternal Dewan Pimpinan Cabang Perhimpunan Mahasiswa Hukum Indonesia Daerah Istimewa Yogyakarta (DPC PERMAHI DIY) Periode 2012-2014 | Email: jamilncera@gmail.com | FB/Youtube/IG/Twitter: @MJAMILSH | Website: http://www.mjamil.my.id.
} 
memulainya dengan memurnikan alam pikiran kita semata-mata untuk membangun bangsa dan negara tercinta ini.

Agar sama persepsi dalam pemaknaan radikalisme, Penulis perlu menjelaskan terlebih dahulu secara sederhana apa itu makna atau pengertian dari radikalisme.

Kamus Besar Bahasa Indonesia (KBBI) memberikan pengertian radikalisme adalah paham atau aliran yang menginginkan perubahan atau pembaharuan sosial dan politik dengan cara kekerasan atau drastis (KBBI, 1995).

Radikalisme merupakan embrio lahirnya terorisme. Radikalisme merupakan suatu sikap yang mendambakan perubahan secara total dan bersifat revolusioner dengan menjungkirbalikkan nilai-nilai yang ada secara drastis lewat kekeraan (violence) dan aksi-aksi yang ekstrem. Ada beberapa ciri yang bisa dikenali dari sikap dan paham radikal, diantaranya; 1) intoleran (tidak mau menghargai pendapat dan keyakinan orang lain), 2) fanatik (selalu merasa benar sendiri; menganggap orang lain salah), 3) eksklusif (membedakan diri dari umat Islam umumnya) dan 4) revolusioner (cenderung menggunakan cara-cara kekerasan untuk mencapai tujuan). (belmawa.ristekdikti.go.id, 24/05/2017).

JRP French \& Bertram Reven dalam bukunya The Basic of Social Power, mereka mengatakan bahwa perbutan kekuasaan dengan menggunakan radikalisme diklasifikasinya sebagai kekuatan pemaksaan (coercive power) yang selalu diluar konstitusional yang lazim disebut kudeta (coup d'etat) (Inu Kencana Syafiie, 1999: 19). Adanya kodisi yang demikian, Penulis jadi berpikir panjang, apa jadinya kekuatan pemaksaan yang sedang di gadangkan oleh kelompok-kelompok tertentu yang akhir-akhir ini sedang berkembang di Indonesia untuk merongrong keutuhan dan warna-warni yang terbingkai rapi dalam kebhinekaannya benarbenar akan terjadi. Jauh-jauh hari, para funding father bangsa ini sudah mendialogkan panjang lebar terkait idiologi mana yang lebih baik di terapkan untuk Indonesia terkasih, akhirnya disepakatilah Pancasila sebagai idiologi dasar negara ini.

Warga Indonesia mayoritas memeluk agama Islam. Jauh sebelum bangsa Indonesia berdiri tegak dan menyatakan kemerdekaannya, yakni pada masa Nabi 
Muhammad SAW, seorang nabi pembawa kedamaian di muka bumi ini, pernah mengingatkan dengan tegas pada umatnya (orang-orang Islam), "Barang siapa membawa senjata untuk mengacau kita, maka bukanlah ia termasuk umatku." (H.R. Bukhâri dan Muslim dari Ibn 'Umar). Hadist tersebut menggambarkan bahwasannya seorang nabi begitu sangat bencinya pada orang-orang yang berbuat kekacauan di tengah masyarakatnya yang beradab, hidup tentram dan rukun dalam kebersaaan yang utuh, kalau ada yang bersikap demikian, tidak segan-segan dikatakan bahwasannya mereka bukan sebagai umatnya.

Dewasa ini, orang yang radikal atau penyebar paham radikalisme sering dikaitkan dengan agama tertentu. Untuk meluruskan pandangan itu, pada prinsipnya semua agama di dunia ini, oknumnya bisa berpotensi sebagai orang yang radikal atau penyebar paham radikalisme, baik itu agama Kristen, Protestan, Hindu, Buddha, Konghuchu, Islam maupun Agama dan kepercayaan lainnya. Oleh karenanya, pelabelan secara massal pada agama tertentu sebagai sarang atau penyebar radikalisme harus kita hindari bersama, apalagi di Indonesia terbingkai dalam Bhineka Tunggal Ika (yang walau pun berbeda suku, ras, agama, dan kepercayaan dalam pribadi masing-masing, namun tetap satu tujuan) yakni tujuan sama-sama meyakini Indonesia sebagai satu tumpah darah dan sama-sama bercitacita menjadikan bangsa Indonesia menjadi bangsa yang besar serta disegani oleh bangsa-bangsa lain (M. Jamil[1], 2016: 24).

Kondisi yang terjadi dewasa ini, baik di warung kopi, bangku kuliah, ruang kajian, ruang seminar, bahkan tulisan-tulisan di media massa sering memperbincangkan semua persoalan dan seluk beluk seputar radikalisme. Pada hakikat dasarnya, istilah dan persoalan radikalisme bukan merupakan konsep yang asing lagi di mata dan telinga kita sebagai bangsa Indonesia. Berkaitan dengan ini, M. Sidi Ritaudina menggambarkan, pada dasarnya secara umum ada tiga kecenderungan yang menjadi indikasi radikalisme yang berkembang dewasa ini, yaitu :

Pertama, radikalisme merupakan respons terhadap kondisi yang sedang berlangsung, biasanya respons tersebut muncul dalam bentuk evaluasi, penolakan atau bahkan perlawanan. Masalah-masalah yang ditolak dapat berupa asumsi, ide, 
lembaga atau nilai-nilai yang dipandang bertanggung jawab terhadap keberlangsungan kondisi yang ditolak (M. Sidi Ritaudin, 2014: 391-392). Sedangkan biasanya yang dilakukan perlawanan adalah hal-hal yang terkadang termaknai belum matang (dimaknai sempit), ujung-ujungnya cepat mengambil sikap sebagai rujukan tindakan tanpa menelaah, mengkaji serta menyaringnya terlebih dahulu.

Kedua, produktifitas radikalisme yang tidak berhenti pada upaya penolakan, melainkan terus berupaya mengganti tatanan tersebut dengan bentuk tatanan lain. Tatanan lain yang dimaksud adalah implementasi penegakan syari'ah Islam dalam negara, karena hanya Islam yang mengandung ajaran dan tata nilai yang sempurna, holistik dan mandiri dalam arti tidak membutuhkan ideologi Barat yang sekuler. Kaum radikalis berupaya kuat untuk menjadikan tatanan tersebut sebagai ganti dari tatanan yang ada. Dengan demikian, sesuai dengan arti kata 'radic', sikap radikal mengandaikan keinginan untuk mengubah keadaan secara mendasar dari semua sistem kehidupan, baik ekonomi, politik, sosial dan negara (M. Sidi Ritaudin, 2014: 391-392).

Pada dasarnya semua upaya pembawaan perubahan ke arah yang lebih baik itu sah-sah saja, selama sikap dan tata cara yang dilakukan tidak menyalahi aturan yang ada. Berbeda halnya bila sikap dan tindakan yang diambil oleh seseorang atau kelompok tertentu bertindak secara radikalisme serta menyalahi peraturan perundang-undangan yang secara legal formal melarangnya, maka sikap kita harus sigap dan mengambil tindakan tegas atas hal itu. Bila tidak bisa dilakukan seorang diri, maka laporkan tindakan-tindakan tersebut pada aparat yang berwenang untuk itu (polisi), biar mereka yang menindak lebih lanjut. Karena kalau kita hanya menonton tanpa megambil tindakan apa-apa, itu sama saja kita melakukan pembiaran untuk itu, efeknya kedepan akan lebih parah, bukan hanya akan berdampak pada kita, bisa jadi juga berdampak pada anak cucu kita, bahkan bisa jadi mengancam keutuhan dan ketentraman bangsa yang selama ini kita jaga dan pelihara bersama.

Ketiga, kelompok radikalis ini memiliki suatu keyakinan yang sangat kuat terhadap kebenaran program atau ideologi yang mereka bawa. Sikap ini pada 
saat yang sama dibarengi dengan panafian kebenaran sistem lain yang akan diganti dalam gerakan sosial, keyakinan tentang kebenaran program atau filosofi sering dikombinasikan dengan cara-cara pencapaian yang mengatasnamakan nilainilai ideal seperti 'kerakyatan' atau kemanusiaan, yang dibarengi dengan sikap emosional dan memberi penilaian bahwa hanya arah dan keyakinan mereka sajalah yang mengandung kebenaran. Bahkan Sayyid Qutb membagi masyarakat, secara ekstrim, menjadi dua golongan yaitu masyarakat yang terdiri dari golongan Allah (hizbullah) dan vis a vis berhadapan dengan golongan syaithan (hizbussyaithan) (M. Sidi Ritaudin, 2014: 392).

Kelompok-kelompok radikalisme sangat kuat dan tekun mendidik kadernya agar menjadi kader yang militan, embrio dari didikan itulah yang akan dijadikan sebagai kaki tangan untuk memuluskan kerja-kerja mereka dalam mewujudkan impian akhir mereka. Sebagai umat bangsa yang meyakini Pancasila sebagai idiologi dasar negara yang sudah final, perlu kita renungkan bersama kemilitansian mereka, dengan menyadari itu semua, kita harus jauh lebih militan dari didikan-didikan mereka untuk mempertahankan Pancasila. Pancasila sudah teruji dapat merawat dan mengharmoniskan berbagaimacam ras, agama, dan kepercayaan yang ada di Indonesia. Karena kalau kita melisik lebih dalam makna Pancasila, tidak ada yang bertentangan dengan nilai luhur yang terkandung dalam Islam.

\section{Strategi BNPT untuk Mencegah Radikalisme}

Dalam bidang pencegahan, Badan Nasional Penanggulangan Terorisme (BNPT) menggunakan dua strategi untuk mencegah radikalisme dan terorisme, Pertama, kontra radikalisasi yakni upaya penanaman nilai-nilai ke-Indonesiaan serta nilainilai non-kekerasan. Dalam prosesnya strategi ini dilakukan melalui pendidikan baik formal maupun non formal. Kontra radikalisasi diarahkan masyarakat umum melalui kerjasama dengan tokoh agama, tokoh pendidikan, tokoh masyarakat, tokoh adat, tokoh pemuda dan stakehorlder lain dalam memberikan nilai-nilai kebangsaan. Strategi kedua adalah deradikalisasi. Bidang deradikalisasi ditujukan pada kelompok simpatisan, pendukung, inti dan militan 
yang dilakukan baik di dalam maupun di luar lapas. Tujuan dari deradikalisasi agar; kelompok inti, militan simpatisan dan pendukung meninggalkan cara-cara kekerasan dan teror dalam memperjuangkan misinya serta memoderasi pahampaham radikal mereka sejalan dengan semangat kelompok Islam moderat dan cocok dengan misi-misi kebangsaan yang memperkuat NKRI (belmawa.ristekdikti.go.id, 24/05/2017).

Strategi kedua, adalah deradikalisasi. Bidang deradikalisasi ditujukan pada kelompok simpatisan, pendukung, inti dan militan yang dilakukan baik di dalam maupun di luar lapas. Tujuan dari deradikalisasi agar; kelompok inti, militan simpatisan dan pendukung meninggalkan cara-cara kekerasan dan teror dalam memperjuangkan misinya serta memoderasi paham-paham radikal mereka sejalan dengan semangat kelompok Islam moderat dan cocok dengan misi-misi kebangsaan yang memperkuat NKRI (belmawa.ristekdikti.go.id, 24/05/2017).

\section{Pancasila sebagai Pencegah Disintegrasi Bangsa}

Dewasa ini banyak orang yang lebih mementingkan kepentingan pribadi atau kelompok daripada kepentingan umum. Akibat dari itu, hilangnya persatuan dan kesatuan diantara kita, sehingga dapat menyebabkan timbulnya disintegrasi bangsa. Kamus Besar Bahasa Indonesia memberi pengertian disintegrasi, adalah hilangnya keutuhan dan kesatuan.

Bila melirik secara umum, disintegrasi bangsa merupakan suatu keadaan dimana suatu bangsa mengalami perpecahan. Mulai dari kondisi tanah air yang dihadapkan pada konflik dan pertikaian serta masalah lain sebagai pemicu terjadinya disintegrasi bangsa. Berbagai akumulasi masalah sosial yang terpendam dimasa lalu, bisa muncul dalam bentuk yang berbeda satu sama lain. Asalkan ada sedikit saja pemicunya, persoalan yang sepele pun dengan cepat bisa meledak, menyebar dan meluas secara cepat (karyatulisilmiah.com, 25/05/2017). Hal demikian perlu kita hindari bersama, agar persatuan dan kesatuan di negeri ini semakin kokoh.

Pencegahan hal-hal yang tidak diinginkan seperti yang disebutkan diatas, terutama disintegasi bangsa, maka peningkatan pemahaman dan penghayatan serta 
pengamalan terhadap nilai-nilai pancasila merupakan suatu condition sine quanon. Nilai-nilai Pancasila dijadikan ukuran-ukuran dalam setiap pengambilan keputusan kebijakan penyelenggaraan negara, terutama dengan mempertimbangkan parameter-parameter keadilan dan keadaban. Hal ini sebagaimana yang diamanatkan dalam konstitusi bahwa pemerintah, penyelenggara negara dan lain-lain wajib memelihara budi pekerti kemanusiaan yang luhur dan memegang teguh cita-cita moral rakyat yang luhur (Armaidy Armawi, 2016: 25). Kita sebagai anak bangsa yang suatu saat nanti akan melanjutkan estafet kepemimpinan dari segala lini negara ini, harus bahu membahu dari sekarang menjaganya, agar kelak tidak hanya kita yang menikmati akibat baiknya, bahkan anak cucu serta cicit kita juga ikut menikmati dan melanjutkan dalam prosesi bernegara.

Pancasila sebagai dasar negara sudah Final, namun masih perlu bahkan harus sering digaungkan diseluruh pelosok dan seantero Nusantara, karena pemaknaan-pemaknaan tiap warga negara berbeda-beda antara satu dengan yang lainnya. Oleh karena itu, perlu campur tangan kita semua untuk menyuarakan itu, lebih-lebih pemerintah harus pro aktif menggaungkan nilai-nilai luhur Pancasila, baik pemerintah di tingkat pusat, lebih-lebih pemerintah tingkat provinsi, kabupaten/kota, kecamatan, desa, bahkan tigkat RT/RW, karene mereka-mereka juga bagian dan unsur terkecil dari pemerintah atau negara.

Akhir paragraf, Penulis ingin mengatakan bahwa tulisan ini masih jauh dari sempurna. Walau dalam ketidaksempurnaannya itu, mudah-mudahan dapat memberi terang dan mampu menyemangati kita untuk turut andil dalam menggaungkan Pancasila dan UUD 1945 sebagai roh dan idiologi dasar negara Indonesia yang harus kita pertahankan bersama keutuhannya, serta mengutuk dengan keras segala bentuk radikalisme dan pelanggaran hukum lainnya yang meresahkan masyarakat, bangsa dan negara. 


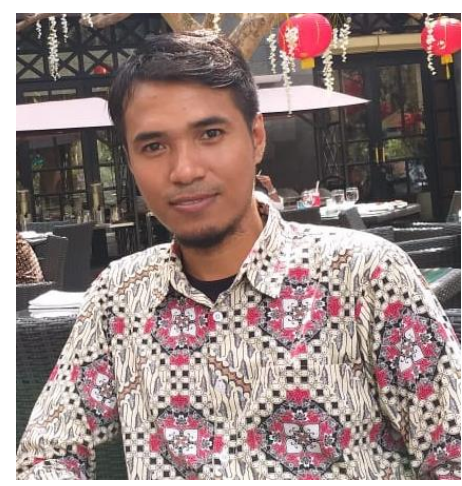

Penulis: M. Jamil, S.H.

Ketua Umum Pusat Studi Mahasiswa Pascasarjana (PUSMAJA) Mbojo-Yogyakarta Periode 2015-2017 | Ketua II Bagian Eksternal Dewan Pimpinan Cabang Perhimpunan Mahasiswa Hukum Indonesia Daerah Istimewa Yogyakarta (DPC PERMAHI DIY) Periode 2012-2014

\section{Ful Sumber Tulisan:}

M. Jamil, "Hukum dan Radikalisme Agama di Indonesia”, Majalah NUSANTARA IKPMDI-Yogyakarta, diterbitkan melalui Dinas Pendidikan Pemuda dan Olahraga (Disdikpora) Daerah Istimewa Yogyakarta, edisi Mei-Juni 2017, lihat Halaman $17-18$. 